\title{
ALGUNAS CONSIDERACIONES SOBRE ESTÉTICA MUSICAL ÁRABE
}

\author{
Manuela Cortés García
}

\section{RESUMEN}

En principio, la poesía considerada como génesis del arte árabe, y, más tarde, la prosa de adab surgieron con la idea de ciencia que destacaba el dominio de la belleza, idea que se proyectaría después sobre la música.

Por otra parte, la aportación griega al legado filosófico y científico árabe clásico, cuya sombra aparece reflejada sobre los primeros tratados de los filósofos y teóricos musicales, entre los que se encuentran alKindī (s. IX) y al-Fārābī (s. X), germinó en la concepción de un nuevo sentido sobre la «belleza».

De esta forma, y desde un observatorio que tiene como punto de referencia el mundo clásico griego, los nuevos parámetros surgirían como consecuencia de su propia identidad e idiosincracia, en los que el patrimonio poético y musical, unido al pensamiento religioso y filosófico, complementarían la taracea de un nuevo concepto, «estética musical».

El estudio de la musica medieval árabe revela que la armonía entre el contenido poético, lingüístico, rítmico y melódico caminaron en paralelo, produciéndose un equilibrio, una relación armónica, y, en definitiva cósmica que les llevó a acuñar un cierto ideal estético basado en la belleza y la emoción artística que despertaba como reflejo de una armonía entre cuerpo y alma, y que facilitaría la unión con lo infinito y la divinidad.

Palabras clave: «Nawba» (suite musical clásica andalusí); «țab» (modo). Escala modal en el occidente musulmán que se corresponde con «maqām» en la árabe-oriental; «Šayarat al-Ṭubū» (Arbol Modal). Arbol donde aparecen representados todos los modos que la integran.

\begin{abstract}
At the beginning, the poetry was considered as the genesis of the arabic art, and after then the prose of $a d a b$, both of them appeared with the idea of the «beauty science». This idea would be projected on the music.

On the other hand, the greek heritage of the classic arabic philosophy legacy was reflected during the first manuscripts of the arabic philosophers and musical theoreticians as al-Kindī (s.IX) and al-Fāräbī (s.X), as a result appeared a new conception of the «beauty» and «aesthetic».

By this way, taking as a point of reference the greek classical world, the new parameters would appear as an result of this own reality and idiosyncrasy. Their poetry and musical legacy, joined to the philosopher and religious mind would complete the work of the «aesthetic musical art».

The study of the arabic middle music prove that the harmony in the poetry, linguiistic and rhitmycal contents, go in parallel with the melodic content until it reached a harmonic relation and in definitive cosmic, and as a result an «aesthetic ideal». This ideal was based on «beauty» and the «aesthetic emotion» produced by the art and all that as reflet to the harmonic until the corp and the spirit and oriented to the spherical work and to the divinity.
\end{abstract}

Key words: Nawha, tabo', šaŷarat al-țubū‘ 


\section{INTRODUCCIÓN}

La escasez de trabajos en el plano de la estetica musical árabe, por parte de críticos y musicólogos contemporáneos, plantea la necesidad de abordar este nuevo reto en la historia de la musicología, especialmente, en su contexto clásico oriental, andalusí y magrebí.

Tomando como punto de referencia el pensamiento de los filósofos árabes clásicos, quienes generalmente incluyen en sus obras un apartado dedicado a la música y su relación con otras disciplinas artísticas y científicas, una parte de este trabajo está orientado a recoger las teorías de percepción de estos filósofos, pensadores y eruditos orientales trasladándolas al contexto medieval de al-Andalus, dada su relación y dependencia no sólo en lo que concierne a pensamiento y cultura arabo-islámica en general, sino sobre todo én lo que respecta a la música, para pasar después a formular las correspondientes interpretaciones.

Como hilo conductor del mismo analizaremos los puntos siguientes aplicados a la música: a) aproximación al concepto estético árabe; b) pensamiento religioso; c) la música en los tratados de los filósofos clásicos; d) visión estética del cantor/a y del músico; e) la estética aplicada a la ornamentación: manuscritos, organología, iconografía y práctica musical; f) armonía entre: poesía-lenguaje-métrica y voz-melodía, y g) armonía, cosmogonía y terapeútica de la música.

\section{APROXIMACION AL CONCEPTO ESTETICO ARABE}

Como preludio a este apartado intentaremos dar una visión global y aproximativa de la historia de los conceptos estéticos árabes y del ideal de la belleza como formas estéticas que conforman la cultura árabe aplicadas a su música, así como de los principios generales que la rigen.

Si tomamos como punto de referencia el concepto que sobre «estética» encontramos en los tratados clásicos medievales, veremos que la definen como una disciplina tradicional dependiente de la filosofía y que tiende a una reflexión sobre el arte como ciencia y su relación con la divinidad, los valores morales y la armonía. 'Frente al ideal medieval, el término «estética» aparece en el concepto contemporáneo basado fundamentalmente en el arte como representación pictórica, la belleza y la teoría de la percepción estética.

Analizando el sentido «estética» a través de las obras de Platón, como fundador de la «ciencia de la belleza» y verdadero intérprete del sentido universal que encierra, vemos que establece una distinción clara, por una parte, entre la concepción de esa «belleza», y por otra, su concepción sobre el arte y los artistas. Según Platón, la idea de belleza no es ni individual ni abstracta, es infinitamente superior al individuo como especie y radica en el mundo inintiligible, es decir, en el lado divino de las cosas, creando así la idea de fusión íntima, de sublimación entre belleza y amor. ${ }^{2}$ Además, distingue entre las tres caras de la belleza reflejadas en: el músico, el amante y el filósofo, que cristalizan a su vez en los tres caminos que conducen a Dios: la música como arte, el amor

1 Vid. «Esthétique». La Grande Encyclopedie Larousse, París (1973), vol. VIII, pp: 4557-4561.

2 Ibid, o. c., p. 4557. 
como belleza y la filosofía como verdad. Asimismo, el concepto de «belleza» que trasciende y emana de Dios aparece unido al de "armonía», frente a la idea de Aristóteles quien, aceptando ciertas ideas de Platón sobre la misma, analiza el sentido de la belleza dominado por las leyes de la lógica, es decir, presentando una concepción del arte regido por un orden.

Más tarde, Plotino, pionero de la escuela Alejandrina y sintetizador de las ideas de sus maestros, Platón y Aristóteles, se nos presenta como el auténtico renovador del pensamiento platónico aportando una nueva concepción estética e introduciendo en ella el sentido del misticismo. Además, frente a Platón y Aristóteles, contempla la estética de la fealdad contrastándola con la belleza como reflejo del bien y de la Providencia. Para Plotino, «el arte tiene por objeto la belleza», de igual forma que «la música tiene por objeto la armonía», ${ }^{3}$ de lo que se deduce su concepción del arte como crisol de belleza y música de armonía en su sentido cósmico.

No obstante, si nos situamos en las coordenadas espacio-tiempo aplicadas a la civilización árabe medieval, encontraremos una concepción distinta a la que rige la civilización occidental. Así, el término estética conocido en el contexto árabe como ilm al-ŷamäl podríamos definirlo como la ciencia o el ideal de la belleza y la emoción estética que despierta. ${ }^{4}$ Sin embargo, a fin de conocer el ideal que mueve estos conceptos estéticos deberemos ahondar en las raices artísticas y estéticas de su pasado cultural.

El origen del «sentido estético», como bien señala Rubiera Mata, podríamos encontrarlo durante el período preislámico conocido como la ŷăhiliyya entre los beduinos, quienes «encerrados en los límites de su península, todavía esquenitas o moradores en tiendas, sintieron la estética de la arquitectura mucho antes de conocer su técnica.... El nómada pre-islámico que recorría la Arabia desértica en espera de la llamada de Alá, era sin duda un esteta capaz de apreciar la belleza allí donde se encontrase, y plasmarla con el único instrumento artístico que conocía: su lengua». Esta sensación que motivaba sus sentidos le llevó a la necesidad de comunicarse, y sería la poesía el instrumento receptor. Más tarde, apoyándose en la voz y el instrumento llegaría a proyectar todo un cúmulo de emociones y sensaciones.

Contemplando la poesía árabe clásica, género por excelencia del arte árabe, vemos como plasma un cierto ideal estético tanto en la belleza de su contenido como en el de su estructura. Fácilmente podemos observar tras su lectura, la belleza de los elementos estéticos que encierra, y que abarcan desde el contraste predominante en la descripción de la belleza física de la amada, hasta la descripción de sus cualidades espirituales o morales. Por otra parte, la belleza aparece además reflejada en su estructura, basada, en el sentido de unicidad plasmado en una sóla rima, en un único metro y en la pureza de la lengua, con esa misma armonía latente que encontramos presidiendo el arabesco, como experiencia única de una unidad decorativa. Con el paso del tiempo, este ideal de belleza cantado por los poetas preislámicos y clásicos ha ido experimentado su lógica evolución y transformación.

3 Vid. E. Krakowski: L'esthétique de Plotin et son influence. París, 1929, p. 125.

4 Vid. «'Ilm al-Djamāl». Enciclopedie de l'Islam. Leiden, 1971, vol. IIII, pp: 1162-63.

5 M.J. Rubiera Mata: La arquitectura en la literatura árabe, datos para una estética del placer: Madrid, 1981, p. 28. 
De este modo, estética como valor cercano al ideal de la belleza, en principio, lo encontramos latente en la perfección de la lengua y la musicalidad del texto coránico, en la rítmica y el contenido de la poesía y la prosa, en los textos relacionados con la belleza y el arte, en la arquitectura, la geometria, la decoración, los tejidos, la caligrafía, las ciencias, las obras filosóficas, el sufismo y el arte islámico en general, tomando como punto de partida la imagen del arabesco.

Profundizando en la historiografía arabo-musulmana vemos que frente a la idea inicial y un tanto profana que del concepto belleza tenían los omeyas, con los abbasíes evolucionó el sentido estético, ya que buscando la armonía del cuerpo, se inclinaron hacia un equilibrio entre la belleza espiritual y la corporal. En este proceso evolutivo intervino de forma clara el pensamiento filosófico de al-Kīndī (s. IX) y al-Fāräbī (s. IX-X) con clara influencia griega e impregnada de las ideas neoplatónicas y del mundo de las esferas celestes de Pitágoras, Platón y Plotino. Los Ijwān al-Ṣafă" (s.X) serían los herederos más directos de este nuevo orden estético, y así lo evidencian sus Rasä $\bar{a}^{+} b^{b}$ proyectándolo a su vez sobre filósofos orientales posteriores entre los que se encuentran Ibn Sinā (s. X-XI) y Safī l-Dĩn al-Armawi (s. XIII), y andalusíes como Ibn Rušd (s. XII) e Ibn Bâŷya (s. $X I I)$, reflejado en el contenido de sus obras.

No obstante, si avanzamos en el tiempo y nos situamos en las expresiones conceptuales que sobre el ideal estético formulan historiadores de la talla de Ibn Jaldūn (s. XIV-XV) a través de la Muqäddima (Prolegómenos), veremos que los criterios varían sensiblemente. A propósito de la música, Ibn Jaldūn dice: «es el arte de establecer una cierta relación entre los sonidos, a fin de proporcionar la belleza sensible al oidon, ${ }^{7}$ es decir, concibe la música en función del placer que proporciona a los sentidos. Considera la poesía como la más noble de las artes de los árabes preislámicos cuyos camelleros utilizaban el canto para estimular el paso de los camellos, mientras los jóvenes la utilizaban como distracción. Añade que los árabes empleaban la palabra gina $\bar{a}^{\prime}$ para modular los versos, tajlil para la recitación cadenciosa de la unicidad de Dios, y tagbir para salmodiar los versículos del Corán ${ }^{8}$. Establece una distinción entre el canto puro entre los nómadas, es decir, desnudo de ornamentación, frente al que se practicaba entre las sociedades sedentarias, mucho más virtual, arte que llegó a su apogeo y perfección durante el período abbasí. Al mismo tiempo hace una distinción clara entre dos tipologías de artes: a) artes necesarias, englobando en ellas a los artesanos, y b) artes nobles clasificándolas en base a sus objetivos, entre las que incluye la medicina, la escritura y la música, ya que poseen un grado de nobleza que las otras no poseen, y todas ellas emanan de Dios por lo que apostilla: «Dios es el creador y el sabio». ${ }^{9}$ Ibn Jaldūn concibe, por tanto la música (ginä) unida a la poesía, y la orienta en sus dos variantes, el aspecto profano y el sentido religioso, en alabanza a Dios y su Profeta (madih), y el canto sufí.

Todo ello induce a pensar que, si queremos hacer una valoración aproximada al ideal estético árabe, deberemos ahondar en las raices artísticas y estéticas de las diferentes épocas. El estudio contextual histórico y el análisis formal en su marco, y a la vista de los datos que disponemos, revela

6 Vid. Shiloah, A., kL'epitre sur la musique des Ikhwän al-Safă’ », en Revue des Etudes Islamiques, 32 (1964), pp.

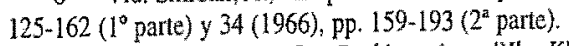

7 Vid. M. de Slane: Les Prolégonénes dThn Khaldoun. París, MDCCCLXVIIl, vol. II, p: 368.

$8 \quad$ Ibid, o. c., p. 419.

9 Ibid, $0 . c, p, 415-426$. 
que aunque evidencia sus orígenes clásicos griegos, deberemos planteamos a posteriori su estudio desde la realidad de la idiosincracia de una estética esencialmente árabe y de las reglas que lo rigen.

Voz, melodía e instrumentos son la triada de elementos esenciales que conforman la música en general. Si aplicamos esa trilogía a la música árabe, veremos cómó también va unida a la poesía, dada su importancia, y al țarab, como la emoción estética que despierta el canto según la interpretación del cantor y que proyecta sobre su audiencia. A menudo, encontramos en los tratados musicales árabes definiciones sobre las cualidades que debe reunir un buen cantor. Entre ellas destacan el manejo del arte de combinar la poesía, la rítmica y la melodía, y sobre las propiedades de la voz insisten en el dominio de la sucesión de melismas y modulaciones encadenadas que deben ir unidas a la mayor o menor emoción que transmite al auditorio.

Sin embargo, frente a la música profana revestida de adornos melismáticos, en la que la estética puede abarcar desde el marco ambiental en el que se desarrolla, a la propia composición de la orquesta, los instrumentos de los que se acompaña y la forma de tañerlo, el decorado e incluso el vestuario de los músicos, el canto coránico se presenta desnudo de todo accidente musical o instrumental.

El recitador (munsid), en la salmodia o recitación (inšäd) de los versículos debe resaltar la entonación que irá acompañada de leves inflexiones de la voz, y sus cualidades artísticas y estéticas deberán ir unidas al atesoramiento de una serie de técnicas como son el arte de marcar o combinar las sílabas con el grado de intensidad que debe presentar dicha modulación. De ello dependerá la carga emotiva que despertará sobre su auditorio. También, en el canto suff́ la estética va unida a la belleza del contenido poético apoyado a veces sobre el instrumento, y a la emoción que despierte en el estado de ánimo de los cofrades o miembros de la cofradía (țariqa), conduciéndoles así al éxtasis, al placer del espíritu, y, en definitiva, a la unión con el Ser Supremo.

Como podemos observar, todo estos condicionantes deberán ser tenidos en cuenta a la hora de plantearnos una valoración sobre los conceptos estéticos de la música árabe en general, y de la medieval en especial.

\section{LICITUD E ILICITUD DEL CANTO}

Numerosos son los textos conservados que presentan la postura de las distintas doctrinas jurídicas respecto al canto y los instrumentos, asi como los hadices que de una forma u otra muestran la actitud del Profeta Muammad frente a la misma. En general, predomina la idea de rechazo en los casos en que puede provocar desviación o alteración en el camino recto hacia Dios. No obstante, y a pesar de las enconadas posturas y de la polémica que a veces presentó la ortodoxia islámica, el canto y la música ha seguido su desarrollo y evolución.

Veamos el pensamiento de algunos historiadores, filósofos y teólogos a propósito de la misma. Ibn 'Abd al-Rabbih (s. X), en su obra antológica al-Iqd al-farId, dedica uno de sus libros o capítulos al canto. Se trata del Kitäb al-yäqüt al-täriya (El libro del segundo rubí), en él plantea dicha problemática apoyándose en los textos del Corán y el hadiz. Por otro lado, el enciclopedista turco Haŷỹă Jalifa en su obra Kašf al-Zunīn 'an asämĭ al-kutüb wa-l-funīn ${ }^{10}$ da una relación de autores 
y obras musicales relacionadas con la teoría y la práctica de la música entre los que se encuentra Ibn Hazm, quien compuso un tratado sobre la licitud del canto, considerado perdido, aunque se conserva su conocida Risāla fị l-ginā' al-mulhĩ (La epístola sobre el canto con música instrumental). ${ }^{11}$

El polígrafo Ibn Hazm, hombre profundamente religioso, cuyo pensamiento se basa en el conocimiento del texto coránico y en las ciencias religiosas en general; llega a la convicción de la autenticidad de la doctrina islámica a través del razonamiento. En la introducción de su Risäla y tras la bismala entra directamente a expresar el motivo que le llevó a escribirla y dice: «Tu deseas que te explique si el canto con música instrumental es lícito o ilícito, puesto que nos han llegado algunas tradiciones (ahādi) que lo prohiben y otras que lo permiten»..2 Aunque desde el principio, y fiel a la doctrina zăhirí, se manifiesta a favor del canto, después expone las tradiciones que la prohiben, insistiendo en la falta de veracidad de las mismas. Documenta en cambio sus teorías sobre la licitud en base a las cadenas de transmisión (asäníd), recogiendo los textos del hadiz, y pasajes de la vida del Profeta y sus compañeros, así como el testimonio de alguna de las escuelas jurídicas apoyándose sobre todo en la hanafi. Finalmente, llega a la conclusión de que todo depende de la intencionalidad y afirma: «Las obras se valoran según las intenciones, y a cada hombre (se le juzgará) según la intención que haya tenido», trayendo además a colación una sentencia del profeta que dice: «los actos del hombre no se valoran más que por las intenciones con que se realizan».13

Algunas de las informaciones recogidas en estas cadenas de transmisores las encontramos a su vez retomadas en los distintos códices que sobre la música profana o religiosa se han conservado, e incluyen las posturas adoptadas por las diferentes escuelas jurídicas respecto al canto ( $a l$-gina $\left.\vec{a}^{\prime}\right)$, la prohibición de vender cantoras (qiyann) y la utilización de instrumentos, e incluso el canto de las plañideras, tomadas en parte de la Sumna. ${ }^{14}$

El tradicionista y sufí sevillano Abü Bakr Ibn al-'Arabri al-Malikī (s.XI) en su obra al-Arida ${ }^{15}$ decía que: «no existía ninguna manera de prohibir que se escuchase el canto de la esclava y que al comprador le estaba permitido adquirir todos los servicios que le fueran de provecho, ya que no había ninguna razón para impedírselo», añadiendo que «los ulemas ya se habían manifestado al respecto y que en sus compendios habían quedado registradas las cosas buenas y si, para ellos, el canto hubiese sido algo prohibido no habría quedado, por tanto, consignado en sus obras y se habria fallado a favor de su invalidación». ${ }^{16}$

Ibn Jaldūn, a propósito del arte de la música profana, dice que se aleja de la concepción del canto coránico basado en el cuidado de la pronunciación de las letras y en el alargamiento de las vocales, poniendo esmero y énfasis en las letras de prolongación, según las normativas establecidas por la escuela coránica a la cual pertenece el recitador, y siguiendo la escuela de los antiguos

11 Vid. Terés, E., «La epístola sobre el canto con música instrumentai de Ibn azm de Córdoba», en al-Andalus, 36 (1971), pp: 203-214.

12 Ibid., o. c., pp. 206.

13 Ibid, o.c., p. 213.

14 Ibid., a. c., p. 207, apartado $n^{\circ} 3$.

15 Ärida $l$-Ahavadi fi sarh al-Tirmid̄̈

16 Apud. Guardiola, D., «Licitud de la venta de esclavas cantoras» en Homenaje al Profesor José María Fóneas Besteiro. Granada (1994), 2, pp. 983.996 , cit. p. 991. 
transmisores. Insiste en que el objetivo del Corán es inspirar devoción y no debe servir de placer a aquelias personas que buscan la percepción de los sonidos agradables en la pureza del enunciado. ${ }^{17}$ Utiliza asimismo la opinión de Mälik ibn Anas, quien desaprobaba el uso de la melodía en la lectura del Corán, y sólo autorizaba la salmodia en la recitación, frente al imán Śfīi ì, que la aprobaba. Como vemos, Ibn Jaldūn hace una distinción clara entre música profana, cuyo objetivo era procurar el placer de los oidos, y música religiosa, cuya belleza radica en el contenido del mensaje divino y en la forma de transmitirlo.

La tradición andalusí conserva algunos fragmentos de códices que describen a grandes rasgos las características de la música durante la época. Observamos sin embargo, que salvo noticas aisladas, en general dan poca información sobre el ambiente social en el que se desarrollaba. No obstante, dado el carácter restrictivo de que gozaban por parte de ulemas y alfaquíes, los códices comienzan con una justificación al contenido, un tanto profano, de los mismos.

Así, el Kunnäs̆ al-Hä'ik o Cancionero llevado a cabo por al-Hā’ik quien recopila la tradición oral de la música andalusí en el siglo XVIII, ${ }^{18}$ a lo largo de la introducción y siguiendo la tradición, atesora el testimonio de algunas cadenas de transmisión del hadiz, destacando la licitud de la misma en un afán de justificación, al mismo tiempo que aparece la idea clara de la función de una música «como portadora de la paz al espíritu». Al-Hā’ik hace una especie de profesión de fe cuando dice: «Damos testimonio de que no hay más Dios que Dios único, sin compañero, cl que concedió a los oidos el privilegio del canto, y nos honró con las notas (nagamät maganat) de las melodías», y continúa: "Alabado sea Dios que nos ha colmado con sus bienes evidentes y ocultos, ${ }^{19}$ y nos ha permitido disfrutar del placer del oído, convirtiéndolo en fuerza para los corazones y pendientes y zarcillos para la oreja, es salud para los cuerpos, con la que los órganos satisfacen sus fuerzas, y alcanzan el extremo de su gozo llevando al espíritu a su satisfacción, y proporcionando la alegría que está unida al vino desde la lactancia, y se hermanada con él en aquello que es útil y provechoso, moviendo lo que estaba quieto con la dulzura de las cuerdas y las melodías de la flauta». ${ }^{20}$

Recoge entre otros testimonios el del tradicionista y sufí sevillano AbüBakr Ibn 'Arabī en su libro al-Äriça, que dice así: «El canto no es lícito», y añade: «y si lo acompaña una bandola (tanbüra) no influye tampoco el hacerlo ilícito, pues todos son instrumentos en los que quedan prendados los corazones débiles, y la gente descansa en ellos, y para descansar del peso del esfuerzo que no todas las almas pueden soportar sin que dependan de ello todos los corazones, la ley coránica lo ha permitido». ${ }^{21}$.

En uno de los pasajes de la introducción, al-Hậ’ ik se detiene y hace la siguiente reflexión: «Si la lectura melódica del Corán no es censurable, menos lo será la de otros textos con métricas.22 $\mathrm{Sin}$ duda, una vez más quiere justificarse, $y$, en este caso, espera que no sea mal interpretado el conte-

17 Vid. Trad. Muquddima (Prolegómenes), p. 416.

18 Muammad al-Husayn al-Hă'ik al-Tituwāni al-Andalusī. Vid. Contés, M., Edición, traducción y estudio del Kunnāš al-Hẳik. Tesis Doctotal. Universidad Autónoma, Madrid, 1995, 995 pp (sin publicar). Los datos y citas que aparecen sobre al-Ha' $\mathrm{H} k$ en este artículo, pertenecen a una copia de este manuscrito de original perdido, llevado a cabo por Muammad Bü asal de Tetuán, propiedad del Dr. Valderrama Martínez, F. Las citas y los pasajes traducidos pertenecen a dicho códice y a la traducción de la edición hecha por $\mathrm{M}$. Cortés.

19 Corán, XXXI,19.

$20 \quad H a \bar{l} \mathrm{ik}, 0 . c, p .1$.

21 Ibid, $0, c$, , p. 5 .

22 Ibid, $0, c, p, 6$. 
nido de los poemas que recoge el citado cancionero. En el epílogo, señala cuál fue el propósito que le llevó a escribir su obra, «transmitir su conocimiento a los artistas», y prosigue: «lo he explicado satisfactoriamente con la intención de ayudarles, de forma que sea bueno para ellos, se sienta atraído el hombre sensato y encuentre descanso el compañero», para terminar diciendo: «pido perdón a Dios Altísimo por cuánto haya proporcionado de vano o divertido, y a El suplico que cubra lo que he compuesto con el velo de la protección, la tolerancia y el perdón». ${ }^{23}$

Dicha introducción está sembrada además de pasajes que destacan la belleza de una música cuya melodía de tipo modal encierra todo un cosmos, y cuyos textos poéticos forman un «corpus» perfecto del cual emana el sentido con el que fue concebida, es decir, «llevar la paz al espíritu» a través de una «armonía» proyectada por la conjunción de melodía, ritmo, modos y poesía, idea que aparece clara en el códice. Cosmogonía y cosmología unidas por una estética cuyo ideal sería, en la música religiosa lograr la fusión del alma con el Ser Amado y lo absoluto, y en la profana la paz del alma a través de la melodía y el contenido poético. Esta sería además, y en definitiva, la conclusión a la que llegarían los polemistas del canto y de la música.

\section{LA MÚSICA EN LOS TRATADOS DE LOS FILÓSOFOS CLÁSICOS}

El estudio de la música árabe así como su concepción sólo puede ser entendida tras el estudio de sus teóricos, al mismo tiempo que filósofos, teniendo en cuenta además la importancia de la filosofía clásica griega como idea fundamental en su formación.

Los Ijwān al-Ṣafā' dedican un amplio capítulo dentro de las Rasā'il (Epistolas) a hablar sobre la importancia de Pitágoras, «el filósofo que concilió el mundo de las esferas después de haber liberado su cuerpo de las ataduras terrenales y de llegar a la sublimación tras la constante reflexión, y gracias (también) a la pureza, a la sustancia de su alma, a la sagacidad de su corazón, y a la música producida por la rotación de las esferas y los astros, por lo que pudo deducir gracias a su naturaleza, los principios que la rigen y su relación con las notas. ${ }^{24}$ En efecto, Pitágoras fue el primero en hablar de esta ciencia, y así lo recogen los teóricos musicales árabes. Después vinieron según los Ijwān, Nicómaco, Ptolomeo, Euclides y otros filósofos. Sobre Ptolomeo dice al-Ḥā’ik: tomándolo del 'Iqd al-farìd de Ibn `Abd al-Rabbih y del Kitäb al-mustatraf de al-Išbīhī: «fue artesano del laúd, amante de la música, y compuso el libro de las ocho notas». ${ }^{25}$

La huella del pensamiento pitagórico se dejó sentir en la escuela filosófica griega, siendo Platón, Aristóteles y Plotino sus mayores seguidores, sirviendo de base junto à Aristoxeno en la formación de la filosofía árabe. Entre los siglos IX al XIII empezaron a aparecer los primeros tratados de música árabe, y sus filósofos y al mismo tiempo teóricos se encargaron de hacer una diferenciación clara entre dos sistemas tonales, uno árabe y otro griego influenciado por la música bizantina, la copta y la persa.

23 Ibid, o. c., p: 227.

24 Ijwān: Rasă'il, p. 156.

25 Hā'ik, cap. III, p. 3. Se refiere a los ocho modos griegos: dórico, hipodórico, frigio, hipofrigio, lidio, hipolidio, mixolidio e hipermixolidio. Véase: 'I $q d, \mathrm{~V}, 22$ (ed. Beirut), y Mustatraf, II, 181 (ed. Beirut). 
Entre los primeros teóricos se encuentra al-Kindī, quien basándose en la teoría de la Armonía Universal de Platón escribió una serie de epístolas entre ellas, Risāla fì aŷzzà jabariya fị l-müsīqà, o la Risāla fĩ l-luhūn wa-l-nagāmāt (Tratado sobre las melodias y las notas) en la que aparece el primer Arbol Modal (Šâarat al-tubü) representado en un cuadro en el que establece la relación entre el laúd y las armonías de la naturaleza. ${ }^{26}$ Su sucesor, al-Fārābĩ en su obra Ṭabaqāt al- ulün (Catálogo sobre las ciencias), incluyó la música en el apartado de las Ciencias, haciendo una división entre música práctica y especulativa. ${ }^{27}$ Más tarde y basándose en la estructura del laúd, implantó su nueva teoría sobre la música árabe recogido en su obra, Kitäb al-mūsíqĩ al-kabìr (El Gran Libro sobre la música) ya que la tonalidad de sus cuerdas y el elemento sonoro de su caja se adaptaba a la gama tonal árabe. ${ }^{28}$

Ibn Sĩnā en su tratado Kitāb al-šifā' incluye la música entre los hechos nacidos de la necesidad del hombre de comunicarse con su entorno. La considera una ciencia, de ahí que cierre su obra de matemáticas (cap. XII) con un compendio de la ciencia de la música basándose en la escuela alejandrina en cuanto a la forma, y en los filósofos griegos, entre los que destaca Pitágoras, Platón y Aristóteles, en su expresión científica. ${ }^{29}$ La concepción de su teoría musical es cosmogónica y pitagórica y hace hincapié en que la labor de la ciencia musical es el estudio de los sonidos y su combinación armónica, así como las reglas que rigen la composición musical, basándose en la armonía y la rítmica. Considera que lo objetivos principales de la música son : a) comunicarse; b) dar a conocer sus ideas; y c) informarse de las de los demás.

Asimismo, los andalusíes dedicaron gran atención al estudio de la música desde el punto de vista de la ciencia. Entre ellos, el cordobés Ibn Rušd (en su tratado Ŷawām $\hat{I}^{\prime} f \grave{I} l$-falsafa le dedica algunos pasajes del Taljị̦. Kitāb al-nafs ${ }^{30}$ en el que retomando las ideas de Aristóteles respecto al sonido, la transmisión y la percepción, incluye nuevas ideas y denominaciones sobre la voz $($ tași $\bar{t})$, el sonido $(s a w t)$ y. las notas musicales (nagamāt $).{ }^{31} \mathrm{Ibn}$ Bäŷŷa, entre otros, dedicó gran atención al estudio de la música desde el munto de vista de la ciencia. Ibn Bāŷŷa, filósofo, poeta y cantor de muwaššąas y zéjeles, escribió según las fuentes un libro sobre música superior al Kitab al-mūsíqà al-kabìra, perdido, aunque si se conserva una Risälat al-alhām (Epístola sobre las melodías) que habla sobre el láud y la forma de tañerlo, basado en teóricos musicales anteriores, en general árabo-orientales ${ }^{32}$.

26 Vid. Al-Kindī. Ed. de Z. Yūiūf. Bagdad, 1965; Trad. Shiloah, A., «Un ancien traité sur le `ūd de Abū Yūsuf alKindī» en I.O.S., 4 (1998), pp. 188-89.

27 Vid. González Palencia, A., al-Fārābì. Catálogo de las ciencias. Edición y traducción castellana. Ed. C.S.I.C. Madrid-Granada, 1953, pp. 48-50 (Ciencia de la música).

28 Vid. Edición de D'Erlanger: La musique arabe, vol. I, pp. 170-179.

29 Vid. Badawī, A; Cruz Hernández, M; García Junceda, J.A. y Gómez Nogales, S., Milenario de Avicena. Cruz Hernández., «La teoría musical de Ibn Sinnā en el Kitzăb al-Š̈fá'. I.H.A.C. Madrid, 1981, pp. 27-36.

30 Vid. Ms. 5000 B.N. de Madrid, 118 fols. vid. 72b-73a.; Catl. Robles ms. XXXVII, pp. 17-18; catl. Shiloah, A. n. 135, pp. 208-209. Ed. de al-Ahwānī, A. F., El Cairo, 1950.

31 Vid. Cortés, M., «Revisión de los manuscritos poético-musicales árabes, andalusíes y magrebíes de la Biblioteca Nacional de Madrid» en IV Congreso Internacional de Civilización Andalusí. Homenaje a D. Emilio Garcia Gómez. Universidad de El Cairo, El Cairo, 1998, pp. 95-108, cit., 98-99.

32 Vid. URI, J., Bibliothecae Bodleianae. Mss. Or: Catalogus, Oxford, 1787, n. 499, ms. Pococke 206, folios 221 verso-222 recto. Shiloah, A., catl. ms. 096, p. 158. Vid. Cortés, M., «Sobre la música y sus efectos terapeúticos en la Epístola sobre las melodías de Ibn Bāŷya» en Revista de Musicología, 19, 1-2 (1996), pp. 11-23. 
El estudio de la música en los filosófos clásicos arabo-orientales y occidentales es imprescindible para entender su música, ya que la consideran como una rama dependiente de la ciencia, de ahí que sea imprescindible en sus obras. Además, tomándola en parte de la filosofía griega, la concibieron con la idea de condensar una armonía cósmica, elevándola al mundo de las esferas celestes y a la unicidad del Creador.

Estos primeros teóricos de la música construyeron sus teorías sobre la base del laúd, aglutinando en él un macro-cosmos y un micro-cosmos conceptual. Sirvieron además de eslabón entre las teorías clásicas griegas y el desarrollo de la música occidental durante la Edad Media europea, contribuyendo con sus obras que fueron traducidas y vertidas a otras lenguas. Con ellos pasaron también sus teorías y la práctica de una música que ha atesorado en su interior la carga simbólica con la que fue creada.

\section{VISIÓN ESTÉTICA DEL CANTOR/A Y DEL MÚSICO}

En el contexto de la música medieval oriental y andalusí, el cantor o cantora y el músico eran considerados en función del ámbito social o musical en el que desempeñaban su función. Predominaban dos categorías, aquellos cantores o cantoras que ejercían la profesión en el medio ciudadano y destacaban por su voz, y los músicos que eran apreciados por su virtuosismo. Ambos, en general, formaban parte de las orquestas palaciegas y estaban preparados para amenizar las fiestas y tertulias de un público aristocrático. Eran reconocidos por la sociedad como profesionales y elegidos dentro del grupo en razón a su habilidad, virtuosismo o perseverancia. En base a estos criterios se establecía la remuneración, y bajo la protección o mecenazgo del emir o califa, pasaban a formar parte de su corte. Existían, además, los recitadores del Corán, que gozaban de una serie de privilegios y respeto dentro de la sociedad.

Quedando fuera de estas dos categorías, se encontraban los músicos y cantores populares que dadas sus necesidades recibían la gratificación en especies o con algunas monedas. La función se limitaba a cantar por las calles, plazas y mercados, ejerciendo de juglares del pueblo. Entre ellos se encontraban aquellos que servían en tabernas y lugares de diversión.

Los Ijwān al-Ṣafă’ en el capítulo «Los aforismos de los filósofos sobre la música» de sus Rasả $i l$, dicen a propósito de las cualidades del músico: «El músico cuando es el maestro de su arte, conduce a las almas hacia la virtud, y aleja de ellas los vicios», y continúan: «el músico es el intérprete de la música y debe explicitarla y si llega a expresar las ideas que contiene la música, hará comprender los secretos de las almas e informará sobre los misterios de los corazones, y si no lo consigue, sólo a él le incumbirá la falta». ${ }^{33} \mathrm{La}$ idea del músico como intermediario entre la naturaleza humana y la divina se pone de manifiesto en el pensamiento de estos filósofos.

Sobre los instrumentistas, Ibn Bāŷŷa en su Risālat al-alhān, basándose en tratados orientales anteriores, nos da una visión de las cualidades que debe reunir un buen laudista. Centrándose en el aspecto terapeútico de la música, eje en torno al cual gira este tratadito, dice a propósito de ellos: 
«Si desea conseguir interpretar las notas perfectas que proporcionan el estado ideal al alma, ha de fijar su atención en los cuatro puntos vitales del cuerpo: pecho, garganta, frente y cabeza» ${ }^{34}$ puntos que a su vez relaciona con las cuatro cuerdas del laúd clásico. Ibn Bāŷŷa en este punto destaca el aspecto sensorial e íntimo del músico, y, también, su papel de mediador procurando el bienestar del alma. Asimismo, resalta la importancia de la posición de los dedos sobre las cuerdas, de tal forma que de ello dependerán los efectos que quiera transmitir al oyente adecuándolo a su estado de ánimo, requisito que considera básico en el aprendizaje de tañer el instrumento. En cierta medida, el filósofo zaragozano viene a sumarse al pensamiento de Ibn `Abd al-Rabbih cuando afirma que: «mediante el proceso del canto, la voz surge del corazón y pasa por los distintos miembros hasta llegar al entendimiento». ${ }^{35}$

La concepción de la música y la melodía en el pensamiento de Ibn Bāŷŷa evidencia el estudio de las fuentes árabes clásicas en la que se pone de manifiesto la visión de música como portadora de paz al espíritu, y de acercamiento a la Causa Suprema.

Al-Hầ’ ik en el capítulo II de su introducción: «Sobre la utilidad de la música y sus reglas» dice a propósito del cantor y de la buena voz: «con ella se alcanza el bien en este mundo y en el otro, porque la melodía induce al hombre a elevar la moral, haciendo el bien, fomentando la armonía entre los familiares, defendiendo el honor y tolerando las faltas, y el hombre llora ante sus pecados y su corazón se debilita ante su dureza» ${ }^{36}$ Aquí, al-Ḥā'ik fiel a la idea de sus antecesores, contempla la visión del cantor y el objetivo de la música como portadores del bien al hombre, y sin alejarse del sentido estético que encierra la voz, le da tal vez un matiz más próximo hacia la espiritualidad y a la reflexión interna.

Respecto a la visión de las esclavas-cantoras (qiy)än), abundan los tratados y los textos que nos hablan de su condición, tipología y características, así como de la función que desarrollaron en la sociedad de su época. En general, las esclavas-cantoras orientales y andalusíes podían proceder de distintas zonas y estratos sociales, condición que determinaba también su función y posición, así como el ambiente en el que se movían. ${ }^{37}$ Nos centraremos, sin embargo, en la visión que de ellas tenía la sociedad para analizar después el valor estético de su quehacer musical.

Existe un número considerable de tratados que abordan el tema de la mujer y la música desde distintas prepectivas, dependiendo de las tendencias más o menos heterodoxas dentro del Islam, ya que a lo largo de los siglos, y hasta el momento actual, su función ha sido y es ampliamente debatida. Así, las diferentes escuelas jurídicas expresan su opinión sobre las mismas considerándolas prohibidas, toleradas o reprobadas. Entre ellas, la escuela šafi $i$ está considerada la más moderada, de ahí que las rechazara sólo en aquellos casos en los que incitaba a los placeres ilícitos. Abundan los textos que destacan la belleza o hablan sobre su vida amorosa. Otros hacen hincapié en su formación musical y literaria, lo que contribuyó a que fueran apreciadas en las reuniones y tertulias de los intelectuales de su época, e hizo que su venta o intercambio se hiciera a precios elevados.

34 Vid. Cortés, M., «Sobre los efectos terapeúticos.....», o. c., p. 15.

35 Vid. 'Iqd, V, p. 8.

36 Hā'ik, p. 11.

37 Vid. Cortés, M., «La mujer y la música en la sociedad arabo-musulmana y su proyección en la cristiana medieval», en Música oral del Sur, 2, Granada (1996), pp. 193-207. 
Abundan las citas sobre la licitud e ilicitud de su venta. Así Ibn al-Arabī al-Mālikī (s.XII) tomándolo de los šâfi íes decía en al- àrida que; «la venta de una cantora se apoyaba sobre la base de que el canto estuviese o no prohibidor ${ }^{38}$. El sabio andalusí 'Abd al-Malik b. Habīb (s.IX) en su tratado sobre música al-ihtiyat li-l-dinn, decía que «no se la podía vender en aquellos lugares en los que se sabía que ella era cantora", y, después, entraba en detalles acerca de la legitimidad o ilegitimidad de tal cuestión, atendiendo al hecho de que el canto tuviese o no intencionalidad». ${ }^{39}$

En los distintos tratados o epístolas dedicados a las cantoras proliferan los poemas que destacan su belleza o el goce que proporcionaba su música. Sirvan de ejemplo estos versos del poeta abbasí Ibn al-Rümī (s. IX):

\section{Ruiseñor de alegre canto que aleja la melancolia y acorta la noche con su dulce trino. \\ Ella tiene tanto brillo en su rostro que parece una luna iluminando la noche. La embriaguez se apodera de ella y la tambalea como una rama en flor sacudida por el viento. \\ Llena los oidos y los ojos de belleza al punto que ya no sé de dónde me viene el gozo, si de escucharla o de miraria. ${ }^{40}$}

A propósito del concepto de belleza aplicado a las esclavas cantoras, el prosista oriental de obras de adab, al-Y̌ahiz (s. VIII-IX) les dedica una extensa epístola conocida como Risā'lat alqiyān (Epístola sobre las cantoras). Respecto a su belleza, establece una valoración a la hora de comprarlas: «la belleza es la plenitud y la proporción», y después aclara: «la plenitud son las proporciones justas....., en cuanto a la proporción es el equilibrio (wazn) de una cosa y no su cantidad» ${ }^{4}$. Más adelante añade: «gran parte de la gente que frecuenta las casas de esclavas-cantoras (qiyān), no acude ni por escuchar la música, ni por el deseo de comprar una (qayna)», insistiendo que es debido a la pasión ( $i s ̌ q$ ) que provocan, de ahí lo desorbitado de sus precios. ${ }^{42}$ Además del amor y de la seducción que despertaban, al-Y̌ăhiz señala que tres sentidos van asociados a las esclavas, sin contar el corazón: a) la vista en la contemplación de una bella y exhuberante esclava, b) su habilidad profesional, y c) y al placer que proporcionaba verla tañer su instrumento de música. ${ }^{43}$

Deducimos de todo ello que, para Y̌ăhiz el ideal estético aplicado a la esclava se basaba en su belleza y proporciones, en cierto modo en sus cualidades artísticas y en la armonía y estética producidas por el maridaje: instrumentista-instrumento. A menudo estas cantoras asistían a clases de canto de algún afamado maestro, 0 iban a formarse a los conservatorios, llegando a formar grupos

38 Apud. Guardiola, D., «Licitud...., o. c., p. 988.

39 Ibid, p. 989.

40 Apud. Sobh, M., «La poesía árabe, la música y el canto». Rvta. Anaquel de Estudios Arabes. Madrid (1995), pp. $149-184$.

41 Vid. Pellat, Ch. «Les esclaves-chanteuses de Gähizł» en Arabica 10 (1963), pp. 121 147., o.c. pp. 135-136.

42 Ibid., o. c., pp. 137-138.

43 Ibid, o. c., p. 141. 
orquestales conocidos como sïtäras. ${ }^{44}$ Tánto en Oriente como en al-Andalus, muchas de ellas eran versadas en ciencias matemáticas y astronomía, y destacaban en algunas disciplinas de las humanidades, como la caligrafía, la poesía o la métrica, de ahí que a veces llegaron a ser reconocidas poetisas, lo que contribuía a incrementar sus precios a la hora de ser vendidas.

El enciclopedista tunecino Tîfăsi (s. XIII) también les dedica un apartado en el volumen XLI de su enciclopedia dedicado a la música y titulado Mut'at al-asmä’fí 'ilm al-samā' (El placer de los oidos ante la ciencia de la audición musical, ${ }^{45}$ centrándose en el estudio de la música musulmana durante el primer periodo de ocupación de la Península Ibérica. Tỉfăsi destaca que algunas de ellas eran expertas en todos los instrumentos, así como en diferentes danzas y juegos dedicados a entretener a su audiencia, y añade que se las conocía como consumadas artistas y recitaban adlibitum largas tiradas de versos. ${ }^{46}$

Resulta curioso la diferencia de trato o consideración que en general recibían estas cantoras con respecto a los cantores, de ahí que al-Rûyâñī (s. XII) ${ }^{47}$ señalara que «la esencia del canto era la distracción que creaba la esclava» y alegando que «los malikíes no rechazaban al esclavo a pesar de que Ibn Habib (s. IX) e Ibn Mawwāz (s. IX), entre otros, hubiesen suprimido tal aceptación» ${ }^{48}$

Conocemos a través del estudio de las fuentes músicales que la visión de los músicos y cantores medievales orientales y andalusíes dependía del lugar en el que llevaran a cabo su arte, es decir, el arte musical iba unido al contexto en el cual se desarrollaba. Sin embargo, mientras los cantores y músicos gozaban en general de cierto respeto, considerándoseles en base a sus cualidades interpretativas, las cantoras, en cambio, eran más valoradas por su belleza quedando a menudo relegadas estas cualidades interpretativas a nivel de canto sólo o instrumental. La figura de la qayna iba unida al sentido estético que en general las envolvía, es decir, a su belleza, a la proporción de sus formas, a la pureza o modulación de la voz, a la recitación de la poesía, e incluso a la armonía estética que engendraba la conjunción armónica que se producía entre cantora e instrumento.

\section{ORNAMENTACIÓN}

El elemento ornamental desarrolla una función primordial en la cultura árabe islámica. Ornamentación basada a veces en la simplicidad de unas formas que emanan de la idea de un sólo Dios creador y único.

Así, el alarife medieval realiza una arquitectura cuyo vacío espacial está lleno de contenido semántico y concebido para è placer de los sentidos. El calígrafo convierte la epigrafía en adorno

44 Término árabe traducido como «cortina», o lugar tras el que se colocaban las orquestas (en general de mujeres) en los palacios y reuniones, evitando así las miradas de los contertulios. Más tarde «sitāra» pasaría a aplicarse a las orquestas. Vid. Pellat., «Kayna», E.I.2., vol. IV, p. 856.

45 Manuscrito depositado en la Biblioteca Nacional de Túnez, titulado Fasl al-jităb fi madärik al-jawwäss al-jams

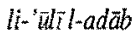

46 Vid. Monroe, J., «Amad al-Tífăši on Andalusian Music» en Ten Hispano-Arabic Strophic Songs in the Moder Oral Tradition, en Modem Philology. University of California, CXXV (1989), pp. 35-44, oc., pp. 38, 40 y 43 .

47 Abū Mahăsin 'Abd al-Wăhid b. Isma' ïl al-Rūyānī al-Safĩ i (502/1108). Autor de al-Bahr. Cf. WI, III, pp. 198-99 (390).

48 Apud. Guardiola, «Licitud....» p. 992. 
y mensaje cargado de sentido poético, transmitiendo los valores de su cultura clásica con una belleza conceptual capaz de crear una atmósfera plenamente sensitiva. El artesano proyecta sobre la bóveda de las cúpulas el sentido de la simetría con una precisión geométrica que surge de la idea de un cosmos único, reflejo a su vez de una armonía que es el resultado de la idea íntima de acercar al hombre a Dios. De esta concepción del arte, por parte del artista musulmán, humana y sensorial, y, al mismo tiempo, divina y espiritual, está impregnada cada una de las manifestaciones artísticas en las que a lo largo de su historia, de una u otra forma ha ido dejando su impronta.

La música árabe clásica cuenta con un rico patrimonio que reune un amplio abanico de códices cuya temática abarca el sentido filosófico, matemático, teórico o científico con el que fue concebida, junto a la pureza de unas formas literarias y musicales que son el reflejo de su vasto acervo cultural y artístico.

Contemplando el contenido de su legado escrito, fácilmente veremos cómo la belleza aflora por sus páginas, apreciando la textura del papel, la variedad en el colorido de su tinta, la estética en la presentación de los textos, o la ornamentación con la que se acompaña. La belleza formal y contextual nos lleva a hacer una reflexión sobre la minuciosidad y el sentido estético con que fueron creados. La mano del autor o del copista sin duda estaba guiada por la estética del arte que pretendían reflejar. Arte que compendiaba la belleza de su escritura en toda su gama, la de una poesía reflejo de su lengua, o el simbolismo de una música que surge de la concepción cósmica y la idea de un Dios único plasmado en la variedad decorativa de su instrumentación, tomando como marco referencial el laúd. Este instrumento primigenio, y epicentro sobre el que se construye la teoría musical islámica, concentra en su construcción el mundo de las esferas celestes, proyectando sobre sus cuerdas todo el simbolismo y la magia del sentido místico que encierra.

Si nos planteamos el objetivo o la idea que guiaba a los teóricos de la música clásica a redactar sus obras, veremos que dos conceptos aparecen claros, por una parte, su deseo de transmitir su legado y dar a conocer sus aportaciones, y, por otra difundir, la idea de «vía» o camino de llegar a Dios. De ahí que el sentido lúdico y sensitivo aparezca recubierto de amplios ropajes divinos, en un afán claro de justificación, no exento tampoco de armonía, estableciendo una comunicación directa entre el hombre y la naturaleza divina.

La organología es el elemento sintetizador capaz al mismo tiempo de proyectar toda la carga emocional que encierra el artista. El término àla en árabe, determina cualquier útil de trabajo, pero también se utiliza aplicado al instrumento de música. La belleza de los instrumentos unida a la decoración que acompaña, nos dan una vez más la idea del sentido estético que encierran. Por otra parte, los testimonios iconográficos medievales en lo que concierne a esta instrumentación, constituye uno de los elementos gráficos más ricos de su historia, generando también toda una literatura.

A pesar de la constante polémica entablada por parte de las diferentes escuelas jurídicas que impedía la reproducción de figuras de seres vivos o representaciones humanas, lo que ha contribuído a que el material no sea lo suficientemente representativo, se conserva en cambio una variedad de piezas que de alguna forma nos comunican la existencia de un arte y una representación que iba unida al desarrollo de la música. Resulta evidente que aunque el mundo musical estuvo dominado por el canto en general, los instrumentos estaban considerados en función del canto que acompañaban, limitándose su papel a asegurar la rítmica, apoyar la voz, animar las danzas, o proporcionar alegría (fara).

La tipología arabo-oriental y andalusí cuenta con aportaciones importantes del sustrato organológico arabo-oriental y mediterráneo, aunque una parte proceda de la civilización persa adapta- 
da después por los árabes, de ahí que elementos de culturas anteriores completen su decoración a través de las miniaturas. Se contemplan tres tipos de organología: de tipo cortesano, de corte militar y finalmente la popular, menos refinada y decorativa, y por lo tanto, más simplista.

El campo figurativo de la organología medieval árabe abarca una amplia gama que va desde los capiteles a diferentes botes, redomas, cajitas y arquetas de marfil, hasta una variada colección de piezas de cerámica esgrafiada con representación de músicos tañendo su instrumento, algunas pinturas murales que recogen escenas festivas, militares o de caza, piletas, etc, reflejo de una cultura cortesana en la que predominaban los instrumentos de cuerda y viento. ${ }^{49}$ Frente a ésta, la iconografía popular tiene como característica general los instrumentos de membrana. La arqueología medieval ha contribuído a complementar o incrementar parte de este conjunto organológico con instrumentos de percusión simple.

Los objetos conservados reproducen una serie de instrumentos que, en general, se repiten, se trata de los cordófonos, sobre los que muestra el amplio abanico de instrumentos que se utilizaban en cada época. En ellos, entra en juego el trabajo de taracea del artesano sobre el instrumento, bordando, incrustando la nacar sobre la nobleza de la madera, o tallando con minuciosidad de orfebre la miniatura, y todo ello envuelto en el amplio abanico estético de formas, contenido y significación que giran en torno a una tendencia clara, resaltar el carácter islámico de su arte.

El estudio de la organología se basa también en la miniatura dibujada en la amplia colección de instrumentos musicales que presentan los códices medievales. Las miniaturas que ilustran estos códices conforman una ornamentación que facilita al mismo tiempo la comprensión de los textos. La belleza de los mismos podemos contemplarla en las primeras representaciones incluídas en tratados orientales entre los que se encuentran el Kitab al-agani (s.IX) de al-Iṣfahānī, en una gran variedad de manuscritos orientales anónimos ${ }^{50}$, o en códices hispanos como los alfonsinos de Las Cantigas de Alfonso $X{ }^{5 \mathrm{I}}$ Posteriormente, los manuscritos andalusíes o los de tradición magrebí presentan a menudo la representación pictórica de diferentes instrumentos, destacando los cordófonos, así como la amplia gama del Arbol Modal (Šâyarat al-tubü), como centro irradiador de una música cargada de significación religiosa y mística. Estos códices hablan por si solos de la belleza, el arte y el sentido estético de toda una época y cultura.

Asimismo, las constantes alusiones a los mismos en el contenido de los versos de las obras poéticas medievales, engarzan en la guirnalda del tiempo, los versos de Ben Guzmán con los del Arcipreste, conformando una orla decorativa de formas diversas y contenido. Música, instrumentos y poesía se entretejen en el amplio abanico estético de formas, color, contenido y significación.

La ornamentación la encontramos también en la esencia de la improvisación (taqsim) musical y en los melismas sobre los que se construye la progresión tonal. Improvisación y melismas parti-

49 Véanse algunos estudios: Alvarez Martínez, R., Los instrumentos musicales en la plástica española durante la Edad Media: los cordófonos, 2 vols. Universidad Complutense de Madrid, 1982. Fernández Manzano, R., «Introducción al estudio de los instrumentos musicales en al-Andalus», en Cuadernos de Estudios medievales, 12-13 Universidad de Granada (1984), pp. 47-77; Cortés García, M., «Organología oriental en al-Andalus» en Boletín de la Asociación Española de Orientalistas, 26 (1990), pp. 303-332.

50 Vid. Shiloah, A. The theory.., ms. Anonymus XVII, pp. 376-382.

51 Vid. Alvarez, R., Los instrumentos musicales en los códice alfonsinos en Alfonso X el Sabio y la música. Madrid, 1987. 
cipan a su vez del arte decorativo musulmán en la voluntad de crear una división infinita en el espacio y el tiempo, de tal forma que las composiciones musicales pierden su sentido estético si se les priva de su aparato omamental.

Dicha ornamentación comporta una matización en la elección de las palabras y una serie de técnicas en la emisión de los sonidos, técnicas vocales e instrumentales, que exigen la habilidad en el juego del timbre, el ritmo, los rellenos en la frase melódica y musical, y todo ello engarzado en el arabesco de formas y mensajes. En general, durante la secuencia de la improvisación (taqșim), la inspiración no debe estar sujeta a determinados cánones, sino que debe ser intuitiva, al mismo tiempo que el cantor (mutrib) debe saber conjugar o combinar perfectamente forma y sentimiento, surgiendo el «duende» (tarab). Llegado a ese momento, el «sentido estético» cambia y se transforma en ciencia de la sensibilidảd, por oposición a estética como ciencia del conocimiento racional.

El aparato ornamental que comporta la esencia de esta música está regida, como podemos ver, por una serie de normativas que aunan arte, armonía y estética tanto en lo que concierne a la belleza en las formas de presentación, como en el contenido y significación de los mensajes que desean emitir. Así, el músico trasciende al mundo de lo inteligible haciendo una abstracción de los sonidos y las formas, buscando la idea y el principio de la armonía, mientras el cantor genera el $a r a b$ como plasmación de la emoción estética que ambos desean transmitir.

\section{ARMONÍA POÉTICO-MUSICAL}

El corpus lírico que conforma la música tradicional árabe medieval en sus tres variantes: oriental, andalusí o magrebí está constituído fundamentalmente por elementos clásicos y populares extraídos de su turāt o patrimonio literario. Poesía y música caminan íntimamente ligadas, de ahí que el texto poético aparezca condicionado al ritmo poético, y este a su vez al modo y al ritmo músical.

Casidas, muwaššahas, zéjeles y mawäl-es, así como sus formas̀ derivadas, conforman el arabesco poético de una música que ha superado los avatares del tiempo. Las muwaššahas y los zéjeles como formas estróficas preferentes en al-Andalus entre los siglos $\mathrm{X}$ al-XIV, formaban también parte de su música, expandiéndose al Oriente y occidente musulmán. En el contexto de la música andalusí, las reglas que regían una interpretación exigían que la temática de las canciones (sana āt), estuviera vinculada al modo musical (tab/maqām) ${ }^{52}$ Así, las canciones que conformaban cada nawba o suite, dada su temática, exaltación del amor humano y divino, la naturaleza, el vino, o la poesía sufí, evocaban en su contenido un sentimiento o estado de ánimo que conllevaba a que se interpretasen en su modo correspondiente y cuyo humor había sido concebido para provocar, en unos casos, o paliar, en otros, un determinado estado de ánimo, de ahí que cada nawba tomara el nombre del tab`o modo del que estuviera compuesta. 
Las fuentes literarias y musicales hablan de la existencia en al-Andalus de 24 modos $(t u b \vec{u})$, creados para ser interpretados a lo largo de las 24 horas del día y dependiendo del tab` o humor, del temperamento del cantor y del público o el ambiente. Esta concepción obligaba a que el texto poético y el modo musical debían ir perfectamente vinculados y armonizados respecto al contenido y temperamento, de igual forma que ramas, tallos y hojas se engarzan formando el arabesco. Dicha realidad resulta evidente en la interpretación secuencial de una nawba, en la que el virtuosismo del músico y el talento del cantor dependerán de su capacidad en saber comunicarse con su auditorio, combinando con la habilidad del artesano, el tab` de la nawba elegida con el ambiente en el cual transcurre. Al-Hā’ik dice a propósito de la melodía y el texto de algunas de las muwaššahas que recoge: «qué efecto no causará su repetición y canto para que el amante desahogue su corazón». ${ }^{53}$

Retomamos de los Ijwān al-Șafā' los principios y las reglas que deben regir las melodías, extraídos de sus Rasä'il, en los que se da una correlación armónica entre los elementos que la integran: «La música está formada por melodías, la melodía por notas y las notas se componen de percusiones y ritmos. Ritmos y melodías se basan en la sucesión alternante de tiempos mociones y silencios. Esto es comparable a su vez con los versos, que se componen de hemistiquios, los hemistiquios a su vez de pies que se designan por paradigmas o metros. Los elementos métricos se fundan en el principio de las combinaciones de letras mudas e inertes. Estos mismos principios se encuentran en el lenguaje articulado formado por palabras las cuales se componen de nombres, verbos y partículas (adawāt), según hemos explicado en los tratados de lengua». ${ }^{54}$ Esta relación entre melodía-notas-ritmos-versos-metros-textos preconizada por los Ijwān al-Ṣafä, denota la armonía entre los elementos que componen la música, de tal forma que debe darse esta conjunción para que se produzca el efecto deseado sobre el oyente y como fórmula perfecta destinada a favorecer su estado de ánimo y el de su entorno, el bienestar espiritual y el acercamiento a Dios.

Ibn Jaldīn en el capítulo dedicado a «El arte del canto» dice: «la ciencia musical nos enseña que las notas tienen determinadas relaciones entre ellas, de tal forma que una puede ser la mitad, la cuarta, la quinta o la undécima parte de la otra».55

De igual forma que ocurría con los modos (țub̄u), también los ritmos ('iqāāt/awzān) poseen una relación estrecha con el elemento métrico inmerso en la lengua. El ritmo musical contribuyó a acortar los metros poéticos adaptando las inflexiones de la voz a las exigencias del poema, o rellenando las frases con prolongaciones melismáticas ( $\check{u} u g l$ ), en definitiva, acomodando el ritmo a la música. LLegado a este punto, los cantores necesitaron aprender los metros, surgiendo a posteriori nuevos metros derivados de los clásicos que eran más aptos para el canto. Este cambio producido durante la Edad de Oro de la música (período abbasí) en Bagdad, y llevado a cabo por la escuela de renovadores de las formas clásicas, ${ }^{56}$ llevó a poetas y compositores a adaptar el ritmo musi-

\footnotetext{
53 Vid. Hằik, Kunnāš, p. 11.

54 Ijwän, 142.

55 Vid. Prolégoménes, 410.

56 Se trata de la polémica suscitada entre los poetas neo-clásicos conservadores y los renovadores que afectó también a la música.
} 
cal al métrico, a fin de facilitar el canto. El Kitāb al-agānī cuenta como el califa y conpositor Walīe b. Yazĩd inventó un metro corte, al-muŷtatt apto para el canto ${ }^{57}$. Este fenómeno podemos encontrarlo también en la música andalusí, en la que predominan los metros cortos sobre los clásicos. De esta forma, el ritmo de la poesía clásica se adaptó a las exigencias del ritmo de la melodía, dándose una total interdependencia entre ellos, y el instrumento sería el encargado de reflejarlo. Al-Hầ’ ik recoge una cita a propósito de esta relación, y cuenta como en cierta ocasión en la que `Abd Allah b. 'Umar ${ }^{58}$ se presentó ante `Abd Allah b. Ya ' ${ }^{5}{ }^{59}$ y junto a él se encontraba una esclava-cantora sobre cuyo regazo reposaba un laúd, al preguntarle sobre el mismo respondió: «Es una medida con la que medimos las palabras». ${ }^{60}$

En cuanto a las leyes que rigen los ritmos poéticos de la lengua árabe y los ritmos musicales, dicen los Ijwạn que «se basan sobre los ocho modos básicos (qawäninn), modos que constituyen los géneros de los cuales derivan los otros ritmos, e igual ocurre con los ocho pies métricos (maqăti $i$ )». ${ }^{61}$ Armonía melódica y métrica vinculada también al lenguaje: «La música posee una cualidad especial que el lenguaje es incapaz de manifestar o expresar por medio de la articulación de palabras, es por esta razón que el alma lo expresa bajo la forma de melodías armónicas», y vinculada también a la espiritualidad del alma: «cuanto la naturaleza escuche estas melodías y se sienta invadida por la alegría y la bondad, entonces, escuchad las palabras que brotan del alma y sus conversaciones íntimas, dejad descansar la naturaleza y no mireis su esplendor ni os dejeis seducir por ella». ${ }^{62}$

A propósito de la armonía Ibn Sīnā dice en el Kitāb al-šifa', que el hombre en su necesidad de comunicarse con sus semejantes y de dar a conocer sus ideas le lleva a emitir sonidos, surgiendo el lenguaje hablado, pero las inflexiones de voz y los cambios de tono llevaron a que «los efectos naturales de los sonidos se fueran enriqueciendo de efectos correlacionales por obra del arte humano hasta conseguir que nos sintamos «seducidos por las combinaciones sonoras»», siendo ésta la base de la armonía. ${ }^{63}$

Esta misma concepción armónica podemos encontrarla respecto al ritmo musical y las notas en los Ijwān: «La armonía de las percusiones emitidas por las cuerdas del músico y la proporción existente entre ellas, así como el placer que producen sus notas, transmiten a las almas, que las esferas y los astros producen en sus respectivos movimientos, una serie de notas proporcionadas, armónicas y deliciosas» ${ }^{64}$

El fenómeno poético-musical que se produce en la música árabe clásica medieval podíamos conceptuarlo como de una perfecta relación armónica y de un auténtico equilibrio en el que los parámetros estéticos que rigen la poesía deben darse también en la música de la cual sè acompaña. El cantor y el músico deben estar vinculados por unos principios estéticos, regidos a su vez por unas reglas que

57 Agänī, vol. VII, p. 17.

58 `Abd Allah b. `Umar al-Jattāb, hijo mayor del califa `Umar, compañero del Profeta Muammad. E.I., vol. I, p. 29.

59 `Abd Allah b. Ya` far b. Abī Tālib, sobrino del califa `Alī. E.I., I, p. 23.

60 Hă'ik, 11.

61 Ijwān, 176.

62 Ijwān, 185.

63 Apud. Cruz Hernández, La teoría musical del Ibn Siñä, p. 31

64 Ijwān, 185. 
armonicen la temática de las canciones con la naturalea de las mismas, con la métrica y la rima o combinación de rimas y su ritmo musical correspondiente, y todo ello bajo la cobertura cósmica de unos modos cuya naturaleza está íntimamente relacionada con el contenido temático que encierra.

\section{ARMONÍA, COSMOGONÍA Y TERAPÉUTICA DE LA MÚSICA}

La música arabo-oriental, de igual forma que la andalusí, están inmersas en el clima mágicomístico en torno al cual gira el macro-cosmos y el micro-cosmos formado por la conjunción de modos (temperamentos), ritmos, melodías, textos, y notas y todos ellos sintetizados en el Arbol Modal (Šầarat al-țubü).

Gran parte de los teóricos árabes han insistido en los efectos de la música, así como en su relación con el arte, la medicina, las matemáticas, la ética, la astronomía, la astrología, Dios y el mundo de las esferas celestes. Esta concepción cósmico-religiosa basada en la escuela neoplatonica fue ampliamente estudiada por la escuela filosófica árabe clásica adoptada por al-Kindī, y el carácter cosmogónico que adquirió la música hizo que sirviera de ayuda al alma en la búsqueda de su perfección. Esta concepción llegó a su punto álgido con la escuela sufí cuyo objetivo era encontrar las vías de purificación del alma a fin de elevarla acercándola a Dios y sirviendo de esta forma de enlace entre el mundo terrenal y el mundo celeste.

El símil del arbol; símbolo semita dentro de la tradición cananea, fue utilizado por los sufíes representado en el Arbol del Universo (Šấarat al-kāwn), y adoptado más tarde por los teóricos árabes para representar a través de las raices expandidas por las profundidades de la tierra y el tronco que eleva sus ramas y frutos al cielo, la naturaleza humana, espiritual y mística que atesora la música.

El origen del Arbol Modal está fundamentado en el término țab` o modo, concebido como temperamento, humor o naturaleza de una música que designa la escala modal y sus características, así como los efectos físico-terapeúticos que ejerce sobre el alma humana. El término tab` lo encontramos en la escuela oriental como maqām. Los cuatro modos principales: al-mầya, alzaydān, al-dayl y al-mazmīm se corresponden con las cuatro cuerdas del laúd y dieron lugar al Arbol y con ellos a la base melódica de la música andalusí derivada de la oriental.

El Cuaternario de las tendencias fundamentales de la Naturaleza y número en torno al cual gira la música, establece aquí una correspondencia con las cuatro cuerdas del laúd, los cuatro humores o temperamentos del cuerpo y los cuatro elementos cósmicos de la naturaleza, y al mismo tiempo con las cuatro estaciones (nanāzil), los cuatro puntos cardinales, y el duodenario zodiacal (simbolismo numérico que aparece como producto de la multiplicidad del cuaternario por el ternario). La simbología numérica del cuatro gira en torno al origen del árbol que encontramos reproducido en los códices antiguos en la figura de un doble cuadrado, sobre el que se colocan los modos básicos así como sus derivados. ${ }^{65}$

65 Vid. Cortés, M., «Nuevos datos para el estudio de la música en al-Andalus en dos autores granadino: aš-Šuštari e e Ibn al-Jaïb», en Revista Música oral del Sur. Granada, 1 (1995), pp. 177-194. Véase representación del doble cuadro modal (p. 190). 
La representación del cuerpo sonoro del laúd clásico árabe de cuatro cuerdas lo encontramos de forma generalizada en manuscritos orientales y andalusíes como símbolo de las ocho notas musicales designadas por las cuatro letras del alfabeto árabe, y síntesis de los cuatro elementos cósmicos. Los Ijwān al-Ṣafa' comparan las 28 casas de la luna con las veintiocho letras del alfabeto

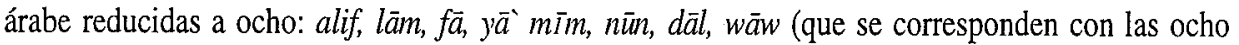
notas musicales), con los ocho paradigmas de la poesía árabe, los ocho ritmos básicos de la música, y los ocho grados del paraíso, así como con los ocho portadores al trono. ${ }^{66}$

La forma de afinar el laúd y de tañerlo aparece en la citada risāla de al-Kindī, Risäla fí l-luhūin wa-l-nagāin (Tratado sobre las melodías y las notas) ${ }^{67}$ y retomada más tarde por teóricos orientales posteriores entre los que se encuentra al-Fārābĩ quien según la teoría que desarrolla sobre el instrumento, establece un sistema matemático de notaciòn basado en el laúd. Ibn Sīnā analizaría en el Kitāb al-šifāà la teoría músico-cosmogónica pitagórica, así como la de al-Fārābī desarrollándola. Después pasaría a al-Andalus donde encontramos, por ejemplo, al zaragozano Ibn Bāŷyya con su Risāla fi l-alhān (Epistola sobre las melodías) en la que retoma las ideas de sus antecesores y en especial de los Ijwān al-Safă'. La cadena de transmisión aparece bastante desdibujada con el paso del tiempo y con la pérdida de tratados andalusíes sobre música, sin embargo es en el Magreb con los moriscos cuando vuelven a aparecer nuevos códices que nos hablan de la continuidad de la transmisión oral y escrita.

Varios códices se suman a la idea primigenia de la representación del laúd y el Arbol Modal con toda su simbología, entre ellos un tratadito del fesí `Abd al-Raḥmān al-Fāsĩ Kitäb al-jumā’ fī 'ilm al-māsāqà (Libro que trata sobre la ciencia de la música y los modos) escrito en el año $1650 .{ }^{68}$ Asímismo, la Biblioteca Nacional de Madrid conserva un manuscrito misceláneo que recoge la figura de un sencillo laúd de cuatro cuerdas sobre las que aparecen dibujadas las cuatro letras correspondientes del alifato árabe: primera cuerda bamm-alif; segunda mațlat-ba; tercera matnā$\hat{y} i m$ y cuarta $z \bar{I} r$ - dal, catalogado en su día por Guillén Robles como Tratado sobre el laúd árabe. ${ }^{69}$

Contemplando la belleza de los documentos iconográfiços del laúd vemos que se produce una proporción (tanāsul) en la numerología como reflejo del macro-çosmos y el micro-cosmos. Al mismo tiempo, podemos hablàr de una estética aplicada en principio a las cuatro cuerdas dobles, a la belleza del colorido de las mismas: negro, blanco, rojo y amarillo y a la significación que reflejan: atrabilis-tierra; flema-agua; sangre-aire y bilis-fuego. Los Ijwän insisten en las propiedades del número ocho ya que los filósofos matemáticos adelantaron que existía una proporción armónica entre los diámetros de las esferas celestes, los elementos cósmicos y los temperamentos humanos, así como una armonía en los sonidos provocando así la paz del espíritu. ${ }^{70}$

66 Ŷăhiz, pp. 164-165.

67 Ed. Z. Yüsüuf, Bagdad, 1965. Vid. Trad. Shiloah, A., «Un ancien traité....», pp. 188-189.

68 Ms. n 5521 del Catálogo de Ahlwardt (Biblioteca Nacional de Berlín). Vid. Edit. y trad. Farmer, H.G., «The notes and their natures» en Studies of Oriental music, vol. II, pp. 568-69.

69 Vid. Robles, G., Catálogo de los manuscritos árabes de la Biblioteca Nacional, Madrid, 1889, apartado «Música», n ${ }^{0}$ 5306-2 (real de la B.N.M.); Shiloah, A., The theor:..., ms. n 325, pp. 415-416. Vid. Farmer, H.G., edit. y trad. «An old Moorish Lute Tutor», en Studies...., pp. 555-563. Cortés, M., «Sobre la música y sus efectos....», pp. 16-21.

70 Ijwān, pp. 136, 140-41. 
Entre las representaciones más antiguas conservadas del arbol representado en un doble cuadrado modal se encuentra el manuscrito magrebí (privado) Fahras al-`awā'id al-mugrīya bi-lmawā id de Abū 'Abd Allāh Muhammad b. Sa`īd al-Marŷ̄ị̣i en el que incluye algunos cantos sufíes del poeta granadino Šsušâtarī (s. XIII). ${ }^{71}$

El Arbol Modal ha generado una serie de poemas didácticos (urŷzas), que fácilmente podemos encontrar en los códices orientales y andalusíes. En lo que concierne a al-Andalus, existe la conocida casida Fi l-țabā'i' wa-l-tubūi wa-l-uṣül (Sobre los humores, los modos y sus orígenes) ${ }^{72}$, atribuída en algunos tratados a al polígrafo granadino Ibn al-Jatīb (s. XIV), y en otros al alfaquí fesí al-Wanšarīṣi (s. XVI) aunque el descubrimiento del manuscrito magrebí de al-Marŷīdī apunta hacia el poeta, cantor y sufí granadino Ššsturī, como posible autor de la misma, de quien tomaría su precursor Ibn al-Jațīb. Al-Ḥā'ik la recoge en su Kunnāš reflejando toda la carga cosmogónica y cosmológica de las teorías neoplatónicas desarrolladas por al Kindī sobre la Armonía Universal y el Universo reflejadas en los modos musicales y sus humores. Veamos sólo algunos versos de esta casida referente a los modos principales, pero que recoge los 24 modos del Arbol Modal, correspondientes a las 24 horas del día:

La melodía de la la voz de al-Dayl y sus derivados, mueve a la melancolía, recíbela cantando.

Por medio de la flema se suscitan los modos:

Zaydān, Ișbahān, Hî̀āz, Hișār y Zawrakand.

La belleza del Māja emociona por poseer la sangre

con Rad, Ramal y al-usayn que es evidente.

La bilis con al-Mazmün hace remontar a sus derivaciones. ${ }^{73}$

A propósito de los humores, dicen los Ijwān al-Șafā’: «los humores del cuerpo son de varios aspectos, así como las naturalezas de los animales también son diferentes. A cada humor o naturaleza le corresponde un ritmo y una melodía cuyo número sólo puede abarcar Dios Todopoderoso y Excelso». ${ }^{74}$

También al-Ḥ̂a'ik incluye este poema corto sobre los modos atribuído a al-Wanšarīsī, basado en las teorías de los Ijwān:

Los humores que existen son cuatro,

de igual forma que los modos musicales.

El primero es la atrabilis, cuyo humor es la tierra

por lo frío y lo seco la ha distinguido la humanidad.

71 Vid. Cortés, M., «Nuevos datos para el estudio.....», pp. 177-194.

72 Manuscrito $\mathrm{n}^{\mathrm{a}}$ 5306-3 de la Biblioteca Nacional de Madrid. Vid. Farmer, H.G., «The natures, elements, and modes, by Lisān al-Dīn Ibn al-Khațīb al-Salmānì, en Studies...., vol. II, pp. 563-568.

73 Hă’ik, p. 13. Vid. Cortés, M., Pasado y presente de la música andalusí. Sevilla, 1996, pp. 82-83 (recogen el poema completo).

74 Ijwān, cap. «Influencia de la música sobre los humores», p. 141. 


\section{La flema tiene como humor el agua, húmeda y fría. \\ Del humor del aire y del calor está regida la sangre. \\ La bilis tiene como humor el fuego, y su calor abrasa \\ por la sequedad que posee por designio de Dios. ${ }^{75}$}

Humores, modos y cuerdas aparecen asimismo ligados al mundo de las esferas celestes conformadas en la Armonía Universal:

«El movimiento coordinado de las esferas producen melodías armónicas, conmovedoras, simétricas y suaves, de la misma forma que ya lo hemos puesto de manifiesto al hablar de los movimientos y las melodías que producen las cuerdas del laúd». La idea de Dios está viva en esta concesión: «si el hombre dotado de inteligencia reflexiona y se somete a un examen profundo sobre esta música, constatará de forma evidente y se convencerá de que es una obra concebida por un Artesano sabio, construída por un Creador vigilante y compuesta por un Compositor benevolente», y continua: «el hombre que logre esta convicción sabrá y verá que los movimientos de dichos cuerpos celestes y las melodías que producen estos movimientos son portadores de placer y felicidad a los moradores del cielo, de la misma forma que la melodía emitida por las cuerdas del laúd proporcionan placer y felicidad a los habitantes de este mundo». ${ }^{76}$

Los efectos que la música produce sobre el alma humana es una constante en los diferentes tratados. Así, los Ijwān recogen en el capítulo dedicado a «Los diferentes efectos de la música (alangäm)» incluído en sus Rasā'il, algunas anécdotas al respecto. Entre ellas, cuenta como un sufí se encontraba escuchando a un lector de Corán que recitaba la Sura, LXXXIX,27, y solicitó del recitador que la repitiera varias veces transcurridas las cuales cayó en éxtasis. ${ }^{77}$

Ibn `Abd al-Rabbih en su obra 'Iqd,a propósito de la buena voz (al-sawt al-hasan) dice sobre los efectos que produce en el oyente: «gran parte de los médicos mantienen la teoría que la voz hermosa corre por el cuerpo y las venas, purifica la sangre, eleva el alma, alivia el corazón, y se estremecen los miembros». ${ }^{78}$ También al-Ḥā'ik recoge en su Kunnāšs diferentes teorías sobre sus efectos tomándolo de tratados anteriores: «la voz hermosa penetra en el cuerpo, fluye por las venas, purifica la sangre, eleva a las almas, tranquiliza el corazón y se estremecen los miembros, ${ }^{79}$ y todas las cosas fatigan al cuerpo salvo la música, por ser descanso del alma, primavera del corazón, distracción del afligido, entretenimiento del solitario y viático del viajero, debido al efecto que produce sobre el cuerpo invadiéndolo». ${ }^{80} \mathrm{~A}$ continuación recoge otro poema del marroquí Abū Muhammad al-Sabbāg (s. XVIII) que dice así:

Aquel que no se conmueva con la dulzura de la música, es ciego de corazón y entendimiento....

75 Vid. Cortés, M., Pasado ......, pp. 77-78. ljwān, p. 141.

76 Ijwān, 174.

77 Ijwān, 192.

78 Vid. 'Ygd. Ed. Beirut, , 1988, vol, V, p. 4 y 7; Kunnāš al-ḥā' $i k$, «Utilidad y reglas de la música y el canto», cap. II, pp. 69-70.

79 Vid. 'Iqd, V, pp, 4 y 7; Mustatraf, II, 172.

80 Hă'ik, p. 10. 


\section{El Enviado de Dios ha dicho:}

«Adornad con vuestras voces las aleyas del Libro Sagrado».....

Los sufies se apasionaron por la música

a fin de avivar el ímpetu del fuego que no ardía.

El Profeta David adornó los salmos acompañado de su flauta ${ }^{81}$ con lamentos en presencia de todos.

¡Por Dios; , el descanso que siente los espíritus

con la melodía, es un secreto oculto al ser humano». ${ }^{82}$

Como podemos observar, la idea de Dios único y creador es una constante en el pensamiento de filósofos y teóricos de la música, Dios como dueño del Universo y Creador Unico, así como sus desvelos por no apartar al oyente de su mirada hacia el Creador. Sirva como conclusión a este apartado el pensamiento de los Ijwān quienes aclaran que la intención de su Risāla sobre la música es: «Mostrar a la gente la unidad de Dios —exaltado sea-, respecto a sus artes específicas; a fin de que este arte sea más fácil de comprender, y que el estudio del mismo sea claro y su práctica más elocuente». Explican además como «los seres son creados unos a partir de otros por deseo de Dios -alabado sea-, la perfección de su ciencia y la sutileza de su arte», y terminan: «Bendito sea Dios, maestro del Universo, el mejor de los creadores, el más misericordiosos de entre los misericordiosos, y el más generoso entre los generosos». ${ }^{83}$

\section{ALGUNAS CONCLUSIONES}

Este estudio ha sido enfocado enfocado hacia el sentir estético en la música y el pensamiento medieval árabe clasico en su contexto oriental y andalusí, intentando dar una visión amplia del ámbito que abarca, a fin de poder determinar, tras su estudio y análisis, las circunstancias que en él incurren. Dos factores importantes han sido tenidos en cuenta, el sentido religioso implícito dada la constante polémica suscitada entre la ortodoxia islámica, siendo un factor determinante en su concepción, y el sentido estético de una poesía que la ha marcado de forma decisiva y con la que llegó a formar un maridaje perfecto.

Armonía poética y musical es el reflejo de cada una de estas ramas del arte árabe. Armonía que aparece fusionada en el contenido, significación e interpretación de una música que tiene el poder de transformar el estado del alma y que eclosiona en el sentir estético que encierra.

El análisis de la esencia de esta música nos lleva a constatar que su sentido estético no está en absoluto alejado de la normativa por la cual se regía el ideal estético en el pensamiento clásico griego, del que se nutrieron los filósofos árabes, adaptándolo después a sus circunstancias y contexto.

Por otra parte, varios conceptos aparecen claros en el quehacer de sus músicos e intérpretes, así como en la visión que intentaron trasmitir a su público, siguiendo, en cierta medida, el sentir de los filósofos árabes, belleza de formas y contenido unido a la idea de emitir un arte que debía ser-

81 Vid. Sobre David: Corán, XXI,79; XXXIV, 10; Biblia: Salmos, IV, V y VI.

82 Hẩik, pp. 11-12.

83 Ijwăn, 142. 
vir de intermediario, de reconciliación entre la naturaleza humana y la naturaleza divina. Esta concepción de arte collevaba, por parte de sus intérpretes, a que gozaran de una paz interna y una belleza capaz de reflejarla y proyectarla sobre su audiencia, ya que de alguna forma debían servir de mediadores acercándoles al mundo de las esferas celestes, y en definitiva hacia el Ser Supremo, a fin de conseguir la paz en la tierra y el bien eterno.

\section{BIBLIOGRAFIA EN NOTAS Y BASICA}

Abül-Faraŷ al-Iṣfahānī, Kitāb al-agānī. Eds: El Cairo, 1869 y Beirut, 1970.

Ahwān̄̄-al, Taljị̦ Kitāb al-nafs, El Cairo, 1950.

Álvarez, R., Los instrumentos musicales en los códices alfonsinos, en Alfonso X el Sabio y la música, Madrid, 1987.

- Los instrumentos musicales en la plástica española durante la Edad Media: los cordófonos, Universidad Complutense de Madrid, 1982, 2 vols.

Cruz Hernández, M., «La teoría musical de Ibn Sīnā en el Kitāb al-Šífā'», en Milenario de Avicena, Madrid, 1981, pp. 27-36.

— Historia del Pensamiento en el mundo islámico, Madrid, 1996.

Cortés García, M., Edición, traducción y estudio del Kunnāš al-Hā̄’ik. Tesis Doctoral, Universidad Autónoma de Madrid, Madrid, 1995, 995 pp.

— «Revisión de los manuscritos poético-musicales árabes, andalusíes y magrebíes de la Biblioteca Nacional de Madrid», en IV Congreso Internacional de Civilización Andalusí. Homenaje a D. Enilio García Gómez. Universidad de El Cairo, 1995, pp. 95-108.

- «Sobre la música y sus efectos terapeúticos en la Epistola sobre las melodías de Ibn Bāŷya», en Revista de Musicología, 19, 1-2 (1996), pp. 11-23.

- «La mujer y la música en la sociedad arabo-musulmana y su proyección en la cristiana medieval», en Música oral del Sur, 2, Granada (1996), pp. 193-207.

- «Organología oriental en al-Andalus», en Boletín de la Asociación Española de Orientalistas, 26 (1990), pp. 303-332.

- Pasado y presente de la música andalusí. Sevilla, 1996.

- «Nuevos datos para el estudio de la música en al-Andalus en dos autores granadinos: aš-Šuštarī e Ibn alJațī», en Música oral del Sur, 1, (1995), pp. 177-194.

D'Erlarguer, R., La musique arabe, París, 1930-1959, vol. I.

Encyclopedie de L'Islam, Leiden, 1971, vol. III.

Encyclopedie Larousse, «Esthétique», París, 1973, vol. VIII.

Fārābī al, Kitāb al-mūsìì̃ al-Kabìr, El Cairo, 1967.

Farmer, H.G., Studies in Oriental Music, Frankfurt am Main, 1986.

Fārūqī-al, L., An Annotated Glossary of Arabian Musical Terms, Connecticut, 1981.

Fernández Manzano, R., «Introducción al estudio de los instrumentos musicales en al-Andalus», en Cuadernos de Estudios Medievales, 12-13, Universidad de Granada (1984), pp. 47-77.

Ferrándis, J., Marfiles y azabaches españoles, Barcelona-Buenos Aires, 1928.

González Palencia, A., al-Fārābì. Catálogo de las ciencias. Edición y traducción castellana, Madrid-Granada, 1953.

Guardiola, M. ${ }^{\text {a }}$ D., «Licitud de la venta de esclavas-cantoras», en Homenaje al Profesor José María Fómeas Besteiro. Granada 2 (1994), pp. 983-996.

Ibn `abd al-Rabbih, 'Iqd al-Farïd, Ed. Beirut, 1988, vol. V. 
Ibn Bāssam, a-Dajīrafĩ mahāṣin ahl al-Andalus, Túnez, 1972, 3 vols.

Ibšihī-al. M, Kitāb al-Muștațraf fı kulli fann al-mustazraf, Ed. Beirut, 1987, vol. II.

Ijwān al-Šafā’, Risāla fì l-mì̄ìqà, Rasā'il, El Cairo, 1947.

Lomba Fuentes, J., Avempace, Zaragoza, 1989.

Maqqarī-Al., Nafh att-tīb, Ed. Ishān `Abbās, Beirut, 1968, 8 vols.

Monroe, J., «Ahmmad Tīfāšī on Andalusian Music», en Ten Hispano-Arabic Strophic Songs in the Modern

Oral Tradition. en Modern Philology. University of California, CXXV (1989), pp. 35-44.

Pellat, CH., «Les esclaves-chanteuses de Gāhił», en Arabica 10 (1963), pp. 121-147.

Peres, H., La poesie andalous en arabe classique au IXème siecle. París, 1953, $2^{2}$ ed.

Puerta Vilchez, J.M., Historia del pensamiento estético árabe, Madrid, 1977.

Kindī-al., Risāla fĩ l-luhūn wa-l-naganät, Bagdad, 1965. Ed. Z. Yūsūf; Trad. Shiloah, A., «Un ancien traité sur le `ūd de Abū Yūsūf al-Kind̄̄», en I.O.S., 4 (1988), pp. 180-195.

Krakowski, E., L'esthétique de Plotin et son influence. París, 1929.

Robles, G., Catálogo de los manuscritos árabes de la Biblioteca Nacional, Madrid, 1889.

Rubiera Marta, M. a J., La arquitectura en la literatura árabe, datos para una estadística del placer: Madrid, 1981.

Safĩ al-Dīn, ’A. M., Kitāb al-adwār, Frankfurt, 1984, Ed. Hāsim Raŷab, Bagdad, 1980.

Shiloah, A., «L'epìtre sur la musique des Ikhwān al-Șafā'», en Revue des Etudes Islamiques, París (1964) pp. 125-162 (1 $1^{\mathrm{a}}$ parte), y (1966) pp. 159-193 (2a parte). The theory of Music in Arabic Writting, Munich, 1979.

Slane de M., Les Prolégoménes d'lbn Khaldoun, París, MDCCLXVIII, vol. II.

Sobh, M., «La poesía árab, la música y el canto», en Revista Anaquel de Estudios Arabes, Madrid (1995), pp. 149-184.

Teres, E., «La epístola sobre el canto con música instrumental de Ibn azm de Córdoba», en al-Andalus, 36 (1971), pp. 203-214.

Uri, J., Bibliothecae Bodleianae, Oxford, 1787.

Valderrama Martínez, F., El Cancionero de al-Hă’ ik, Tetuán, 1954.

Tūma, H.H., La musique arabe et les traditions musicales, París, 1977.

Manuela Cortés García.

34, Muammad Mazhar, apto.15. Zamalik. El Cairo (Egipto). 